\title{
Paenibacillus macquariensis subsp. defensor subsp. nov., isolated from boreal soil
}

\author{
Tamotsu Hoshino, ${ }^{1,2}$ Takuto Nakabayashi, ${ }^{1,3}$ Kikue Hirota, ${ }^{1}$ \\ Toshihide Matsuno, ${ }^{1,4}$ Ryuuichi Koiwa, ${ }^{1,3}$ Seiichi Fujiu, ${ }^{1,3}$ Izumi Saito, 1,2 \\ Oleg B. Tkachenko, ${ }^{5}$ Hidetoshi Matsuyama ${ }^{3}$ and Isao Yumoto ${ }^{1,4}$
}

Correspondence Isao Yumoto i.yumoto@aist.go.jp

\author{
${ }^{1}$ Research Institute of Genome-based Biofactory, National Institute of Advanced Industrial Science \\ and Technology (AIST), Sapporo 062-8517, Japan \\ ${ }^{2}$ Graduate School of Science, Hokkaido University, Sapporo 060-0810, Japan \\ ${ }^{3}$ School of Engineering, Hokkaido Tokai University, Sapporo 005-8601, Japan \\ ${ }^{4}$ Graduate School of Agriculture, Hokkaido University, Sapporo 060-0890, Japan \\ ${ }^{5}$ Main Botanical Garden named after N.V. Tsitsin, Russian Academy of Sciences, Moscow 127276, \\ Russia
}

Two Gram-variable, aerobic, motile, rod-shaped, endospore-forming bacterial strains, M4- $2^{\top}$ and M4-1, were isolated from soil samples collected from Oblast Magadan, Russian Far East, as micro-organisms antagonistic to the psychrophilic phytopathogenic fungus Typhula ishikariensis. Strains M4-2 ${ }^{\top}$ and M4-1 were identified as members of the genus Paenibacillus by phenotypic and phylogenetic analyses based on 16S rRNA gene sequences. The strains contained anteiso$\mathrm{C}_{15: 0}$ as the major fatty acid (63.0-64.7\%) and MK-7 as the major isoprenoid quinone. The DNA $\mathrm{G}+\mathrm{C}$ contents were 42.8 and 41.7 mol\%, respectively. $16 \mathrm{~S}$ rRNA gene sequence analysis showed that strains M4-2 ${ }^{\top}$ and M4-1 exhibited high similarities with Paenibacillus macquariensis DSM $2^{\top}$ (99.5 and 99.7\%, respectively) and Paenibacillus antarcticus LMG $22078^{\top}$ (99.4 and $99.5 \%$, respectively). There were no clear differences in the phenotypic characteristics and chemotaxonomic and phylogenetic data between the novel isolates and $P$. macquariensis DSM $2^{\top}$. DNA-DNA hybridization experiments between strain $\mathrm{M} 4-2^{\top}$ and $P$. macquariensis DSM $2^{\top}$ and $P$. antarcticus LMG $22078^{\top}$ revealed reassociation values of 56 and $49 \%$, respectively. Multilocus sequence analysis confirmed the differences between the new isolates and reference strains that were observed with the DNA-DNA hybridization studies. On the basis of the results described above, it is proposed that the isolates represent a novel subspecies of $P$. macquariensis, Paenibacillus macquariensis subsp. defensor subsp. nov. The type strain is M4-2 ${ }^{\top}\left(=\right.$ JCM $14954^{\top}=$ NCIMB $\left.14397^{\top}\right)$.
Snow moulds are psychrophilic or psychrotolerant fungal pathogens of perennial grasses and winter cereals in the

Abbreviations: meso-DAP, meso-diaminopimelic acid; ITS, internal transcribed spacer; MLSA, multilocus sequence analysis.

The GenBank/EMBL/DDBJ accession numbers for the 16S rRNA gene sequences of strains M4-2 ${ }^{\top}$ and M4-1 are AB360546 and AB360547, and of strains M4-1 and M4-2 ${ }^{\top}, P$. macquariensis DSM $2^{\top}$ and $P$. antarcticus LMG $22078^{\top}$, for the rpoB sequences are AB468054AB468057, for the 16S rRNA gene and 16S-23S ITS sequences are AB468952-AB468955, and for the gyrB sequences are AB469015AB469018, respectively.

A table of DNA-DNA reassociation values and figures showing the macromorphology of Typhula ishikariensis co-cultured with Paenibacillus macquariensis subsp. defensor subsp. nov. and an extended phylogenetic tree of the genus Paenibacillus based on 16S rRNA gene sequences are available as supplementary material with the online version of this paper. northern hemisphere (Hoshino, 2006). Some chemical fungicides have been developed for snow mould diseases, but a surplus of fungicides in the soil can pollute underground waters (Katsura et al., 1994). Studies of the biological control of snow moulds have been carried out using non-pathogenic psychrophilic fungi such as Typhula phacorrhiza (Hsiang et al., 1999) and psychrotolerant bacteria such as Pseudomonas fluorescens (Oshiman, 2000). However, these candidates are not suitable for processing as biocontrol preparations because of their heat sensitivity. Kim et al. (1997) suggested that cold-adapted, endospore-forming bacteria could be potential biocontrol agents against snow moulds.

We have isolated many spore-forming, cold-adapted bacteria from various soil materials in the Arctic and the 
frigid zone and we have selected strains that showed antagonistic activities against the psychrophilic fungal pathogen Typhula ishikariensis. Strains M4-2 ${ }^{\mathrm{T}}$ and M4-1, belonging to the genus Paenibacillus, were isolated from the frigid zone. The genus Paenibacillus comprises members of rRNA group 3 as defined by Ash et al. (1993) and this genus includes several psychrotolerant species from Antarctica, including P. antarcticus (Montes et al., 2004), P. cineris and P. cookii (Logan et al., 2004), P. macquariensis (basonym: Bacillus macquariensis; Marshall \& Ohye, 1966), P. validus (Pepi et al., 2005) and P. wynnii (Rodríguez-Díaz et al., 2005). Another isolate from Antarctic ice that was phylogenetically related to the genus Paenibacillus was described by Christner et al. (2001). However, only a few species have been isolated in the Arctic ( $P$. polymyxa in Devon Island; Jordan et al., 1978) and the frigid zone ( $P$. borealis in Finland; Elo et al., 2001). In this study, we conducted phenotypic characterizations, chemotaxonomic analyses and phylogenetic analyses based on 16S rRNA gene sequences and DNA-DNA reassociation values. The results show that the isolates should be classified in a novel subspecies of $P$. macquariensis.

Strains $\mathrm{M} 4-2^{\mathrm{T}}$ and M4-1 were isolated from boreal soil samples collected from the Koni Peninsula, Magadan Nature Reserve, Oblast Magadan, Russian Far East. A soil sample $(0.5 \mathrm{~g})$ was suspended in sterilized water $(5 \mathrm{ml})$ and treated at $80{ }^{\circ} \mathrm{C}$ for $2 \mathrm{~h}$, and serial decimal dilutions of the suspension were mixed with a nutrient agar medium (Eiken Chemical) and plated. After incubation at $10{ }^{\circ} \mathrm{C}$ for 14 days, colonies were cultured in $5 \mathrm{ml}$ nutrient broth (Eiken Chemical) at $10{ }^{\circ} \mathrm{C}$ with vigorous shaking for 7 days. The fungus T. ishikariensis strain Esashi was cultured on potato dextrose agar (Difco) at $10{ }^{\circ} \mathrm{C}$ for 14 days. Liquid bacterial inoculum $(10 \mu \mathrm{l})$ was placed drop-wise on the fungus and the isolated bacterium and fungus were co-cultured at $10{ }^{\circ} \mathrm{C}$ for 30 days. Strains M4-2 ${ }^{\mathrm{T}}$ and M4-1 inhibited the mycelial growth and sclerotium production of $T$. ishikariensis (see Supplementary Fig. S1, available in IJSEM Online). As far as is known, the inhibition of sclerotium production by a bacterium has never been demonstrated in previous studies; however, the characteristic disappeared during repeated subcultures.

For the phylogenetic analysis of strains M4- ${ }^{\mathrm{T}}$ and M4-1, DNA was extracted using a DNA extraction kit (Isoplant II; Nippon Gene), the 16S rRNA gene was amplified by PCR with primers 9F ( $5^{\prime}$-GAGTTTGATCCTGGCTCAG-3') and 1541R ( $5^{\prime}$-AAGGAGGTGATCCAGCC-3') and the purified PCR product was sequenced according to the methods of Matsuyama et al. (2006). The complete 16S rRNA gene sequence was compiled using GENETYX (Software Development). Multiple alignments of the sequence were performed using CLUSTAL W (Thompson et al., 1994). A phylogenetic tree was constructed by the neighbour-joining method (Kimura, 1983; Saitou \& Nei, 1987). Sequence similarities were calculated using GENETYX. The level of DNA-DNA relatedness was determined fluorometrically by the method of Ezaki et al. (1989).

Results of the comparative analysis of the 16S rRNA gene sequence of strains M4-2 ${ }^{\mathrm{T}}$ (1551 bp) and M4-1 (1548 bp) showed that these strains were phylogenetically affiliated to species of the genus Paenibacillus. Similarity with previously reported strains was determined and phylogenetic trees were constructed with the neighbour-joining method (Fig. 1 and Supplementary Fig. S2 in IJSEM Online). Strains M $4-2^{\mathrm{T}}$ and M4-1 were included in a subcluster within the genus Paenibacillus, with the closest relative being $P$. macquariensis DSM $2^{\mathrm{T}}$. The $16 \mathrm{~S}$ rRNA gene sequence similarities between strains M4-2 $2^{\mathrm{T}}$ and M4-1 and P. macquariensis DSM $2^{\mathrm{T}}$ and P. antarcticus LMG $22078^{\mathrm{T}}$ were 99.5 and $99.7 \%$, and 99.4 and $99.5 \%$, respectively. The $16 \mathrm{~S}$ rRNA gene sequence similarities to the other strains tested were below $96 \%$. Stackebrandt \& Goebel (1994) suggested that a sequence similarity greater than $97 \%$ indicates conspecificity.

To further verify the taxonomic position of strains M4- $2^{\mathrm{T}}$ and M4-1, DNA-DNA hybridization experiments were

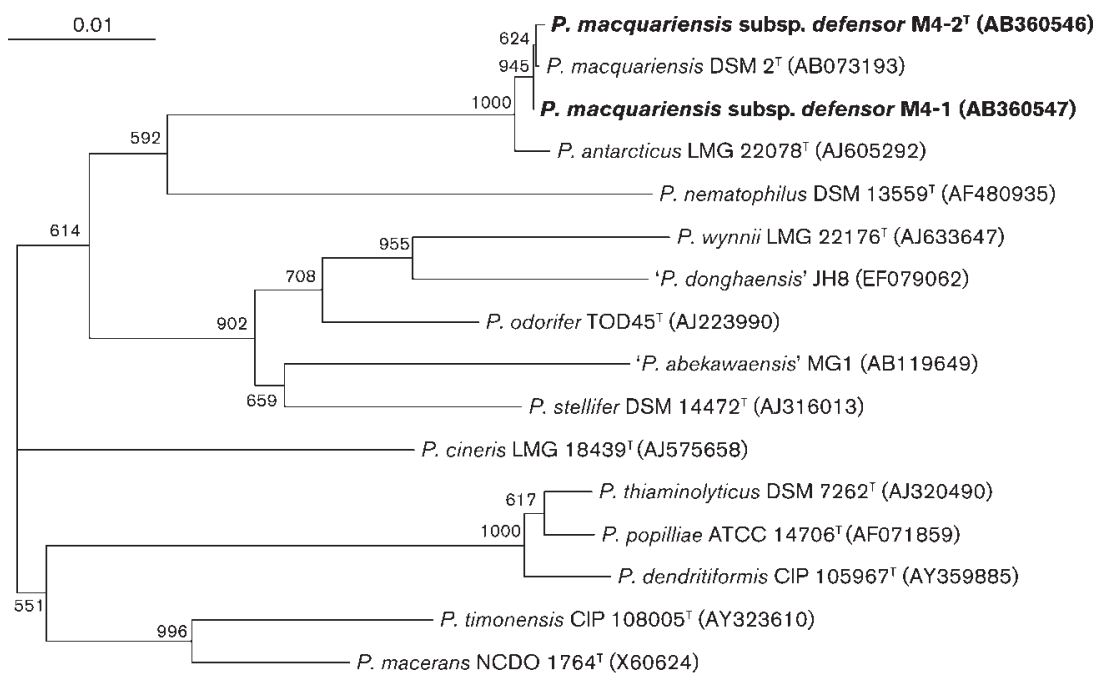

Fig. 1. Phylogenetic tree based on comparative analysis of $16 \mathrm{~S}$ rRNA gene sequences of strains $M 4-2^{\top}$ and M4-1 and phylogenetically related species of the genus Paenibacillus, constructed with the neighbour-joining method. Bootstrap values ( $>50 \%$ ) based on 1000 resamplings are shown at branch nodes. Bar, 0.01 substitutions per nucleotide position. 
performed. Using DNA from strain $\mathrm{M} 4-2^{\mathrm{T}}$ as the probe, DNA-DNA reassociation values of 56 and $49 \%$ were obtained with $P$. macquariensis DSM $2^{\mathrm{T}}$ and P. antarcticus LMG $22078^{\mathrm{T}}$, respectively (Supplementary Table S1). Using DNA from P. macquariensis DSM $2^{\mathrm{T}}$ as the probe with the most closely related three strains, M4-2 $2^{\mathrm{T}}$, M4-1 and P. antarcticus LMG $22078^{\mathrm{T}}$, revealed similar results. These results confirm that strains $\mathrm{M} 4-2^{\mathrm{T}}$ and M4-1 have a distinct taxonomical position among the recognized species of the genus Paenibacillus.

Although the isolates could not be separated from $P$. macquariensis DSM $2^{\mathrm{T}}$ on the basis of the 16S rRNA gene sequence analysis results, the DNA-DNA reassociation results showed that the isolates were distinct from $P$. macquariensis DSM $2^{\mathrm{T}}$. To confirm the above results, multilocus sequence analysis (MLSA) was performed. Sequences of the rpoB, 16S rRNA and 16S-23S ITS and gyrB genes were obtained for the new isolates, $P$. macquariensis DSM $2^{\mathrm{T}}$ and $P$. antarcticus LMG $22078^{\mathrm{T}}$ with the primer sets and amplification conditions described by Dahllöf et al. (2000), Xu \& Côté (2003) and Yamamoto \& Harayama (1995), respectively. The amplified DNA fragments were cloned into a pT7Blue-2 T-vector (Novagen), according to the manufacturer's instructions. Transformants were selected on LuriaBertani agar plates containing ampicillin $\left(60 \mu \mathrm{g} \mathrm{ml}^{-1}\right)$, X-Gal (30 $\mu \mathrm{l} 0.4 \% \mathrm{X}$-Gal per plate) and IPTG $(30 \mu \mathrm{l} 0.1 \mathrm{M}$ IPTG per plate). Plasmids were extracted from positive clones and the nucleotide sequences of their inserts were determined with a BigDye Terminator v3.1 cycle sequencing kit (Applied Biosystems) and analysed using an ABI 3100 sequencer (Applied Biosystems). Neighbour-joining trees of the sequences of the $r p o B, 16 \mathrm{~S}$ rRNA and 16S-23S ITS and $g y r B$ genes showed that the isolates could be distinguished from P. macquariensis DSM $2^{\mathrm{T}}$ (Fig. 2a, b, c). Comparing strain $\mathrm{M} 4-2^{\mathrm{T}}$ with strain M4-1, P. macquariensis DSM $2^{\mathrm{T}}$ and P. antarcticus LMG $22078^{\mathrm{T}}$, the $r p o B$ gene sequence similarities were $99.1,98.9$ and $64.6 \%$, the $16 \mathrm{~S}$ rRNA gene and 16S-23S ITS sequence similarities were $100,98.0$ and $96.8 \%$ and the $\operatorname{gyrB}$ sequence similarities were 99.6, 98.0 and $92.9 \%$, respectively. Thus, the MLSA data supports the DNA-DNA hybridization results.

The morphological, physiological and biochemical characteristics of strains M4-2 $2^{\mathrm{T}}$ and M4-1 and reference strains were examined according to the methods of Barrow \& Feltham (1993) and Montes et al. (2004). DNA G+C content was determined according to the method of Tamaoka \& Komagata (1984). Whole-cell fatty acid and isoprenoid quinones were analysed as described previously (Yumoto et al., 1998, 2001). meso-Diaminopimelic acid (meso-DAP) in the cell wall was identified by TLC (Staneck \& Roberts, 1974). Cells grown at late-logarithmic to earlystationary phase in nutrient broth (Eiken Chemical) were used for the chemotaxonomic analyses.

The cultural properties and cell morphology of strains M4-2 $2^{\mathrm{T}}$ and M4-1 are given in the species description. The physiological characteristics that could be used to differentiate strains M4- $2^{\mathrm{T}}$ and M4-1 from their closest phylogenetic relatives are listed in Table 1. The DNA G $+\mathrm{C}$ contents of strains M4-2 ${ }^{\mathrm{T}}$ and M-4 were 42.8 and $41.7 \mathrm{~mol} \%$, respectively, which are within the range observed for members of the genus Paenibacillus (Shida et al., 1997). The fatty acid analysis of strains M4-2 ${ }^{\mathrm{T}}$ and M4-1 (Table 2) revealed that anteiso$\mathrm{C}_{15: 0}(63.0-64.7 \%)$ and iso- $\mathrm{C}_{15: 0}(14.9-15.6 \%)$ were the predominant fatty acids. This fatty acid profile was almost the same as those of members of the genus Paenibacillus (Ash et al., 1993), and anteiso- $C_{15: 0}$ is the predominant fatty acid in all members of the genus Paenibacillus (Ash et al., 1993; Shida et al., 1997). Strains M4-2 ${ }^{\mathrm{T}}$ and M4-1 contained lower percentages of iso- $\mathrm{C}_{13: 0}$ and anteiso- $\mathrm{C}_{13: 0}$ than $P$. macquariensis DSM $2^{\mathrm{T}}$ and $P$. antarcticus LMG $22078^{\mathrm{T}}$. HPLC analysis of isoprenoid quinones isolated from strains M4- $2^{\mathrm{T}}$ and M4-1 revealed that menaquinone- 7 was the major quinone. Cell walls from the new isolates contained meso-DAP.

All of the characteristics determined for strains $\mathrm{M} 4-2^{\mathrm{T}}$ and M4-1 are in accordance with those described for the genus Paenibacillus. Phylogenetic analysis based on the 16S rRNA gene sequence indicated that the isolates are very similar to P. macquariensis DSM $2^{\mathrm{T}}$ and the paucity of phenotypic and chemotaxonomic differences do not support the assignment of these new strains to a novel species. However, DNA-DNA reassociation and MLSA results indicate that the two isolates are distinct from $P$. macquariensis DSM $2^{\mathrm{T}}$. Therefore, we propose to designate them as a subspecies of $P$. macquariensis, according to the species concept of prokaryotes (Rosselló-Mora \& Amman, 2001; Stackebrandt et al., 2002).

\section{Description of Paenibacillus macquariensis subsp. defensor subsp. nov.}

Paenibacillus macquariensis subsp. defensor [de.fen'sor. L. n. defensor (nominative in apposition) defender, protector, because the isolates inhibit the production of sclerotia by the psychrophilic phytopathogenic fungus Typhula ishikariensis].

Cells are rod-shaped $(0.5-0.9 \times 1.9-3.5 \mu \mathrm{m})$ and motile by means of peritrichous flagella. Oval spores form centrally in swollen sporangia. Colonies grown on nutrient agar and potato dextrose agar are circular, slightly convex, bright and cream coloured. Cells are facultatively anaerobic and Gram-variable. Cells grow between 4 and $31{ }^{\circ} \mathrm{C}$ (optimum $10-15{ }^{\circ} \mathrm{C}$ ). Oxidase- and catalase-positive. Nitrate reduction, production of dihydroxyacetone and VogesProskauer reaction are negative. Positive for $\beta$-glucosidase and $\beta$-galactosidase. Hydrolyses starch and DNA, but not casein or gelatin. The following substrates are utilized for growth and acid production: ribose, D-fructose, L-arabinose, D-xylose, methyl $\alpha$-D-xyloside, D-glucose, methyl $\alpha$-Dglucoside, gluconate, amygdalin, galactose, mannitol, $\mathrm{N}$ acetylglucosamine, arbutin, salicin, lactose, cellobiose, maltose, melibiose, melezitose, D-mannose, sucrose, methyl 
(a) 0.1

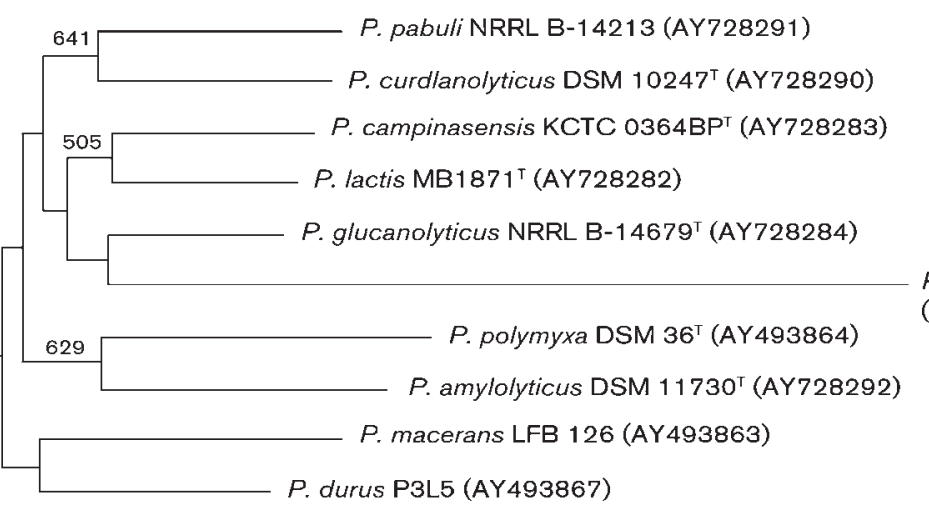

$P$ antarcticus LMG 22078 (AB468057)

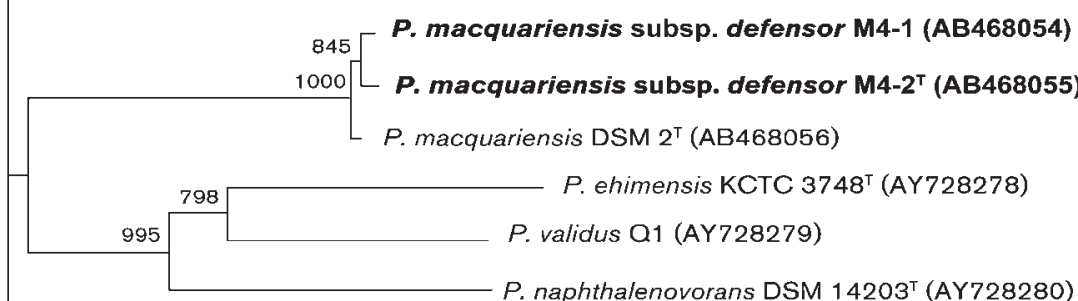

1000 P. massiliensis 2301065 ${ }^{\top}$ (AY728294)

P. daejeonensis KCTC $3745^{\top}$ (AY728293)

(c)

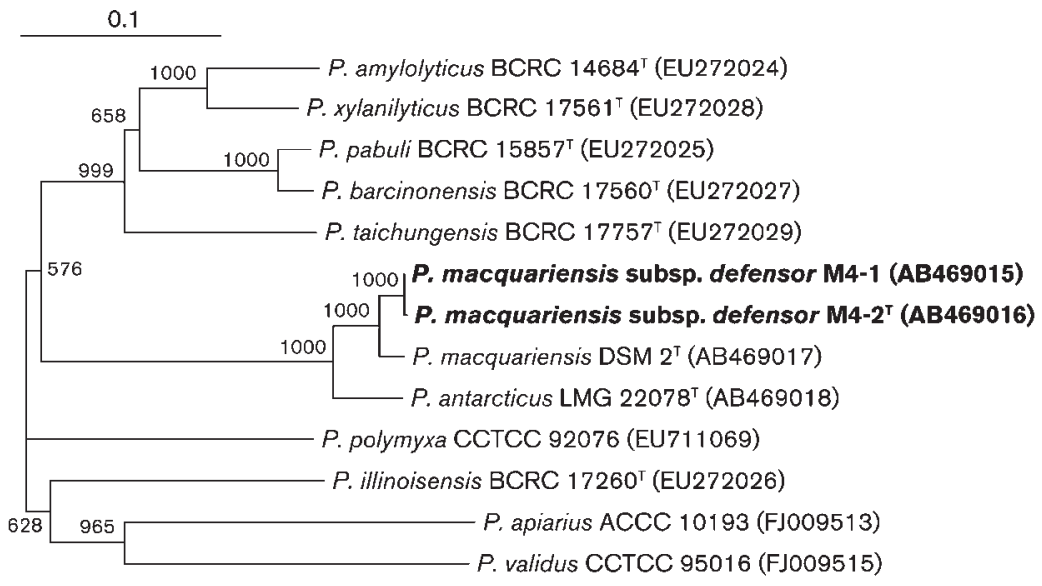

(b) 0.1

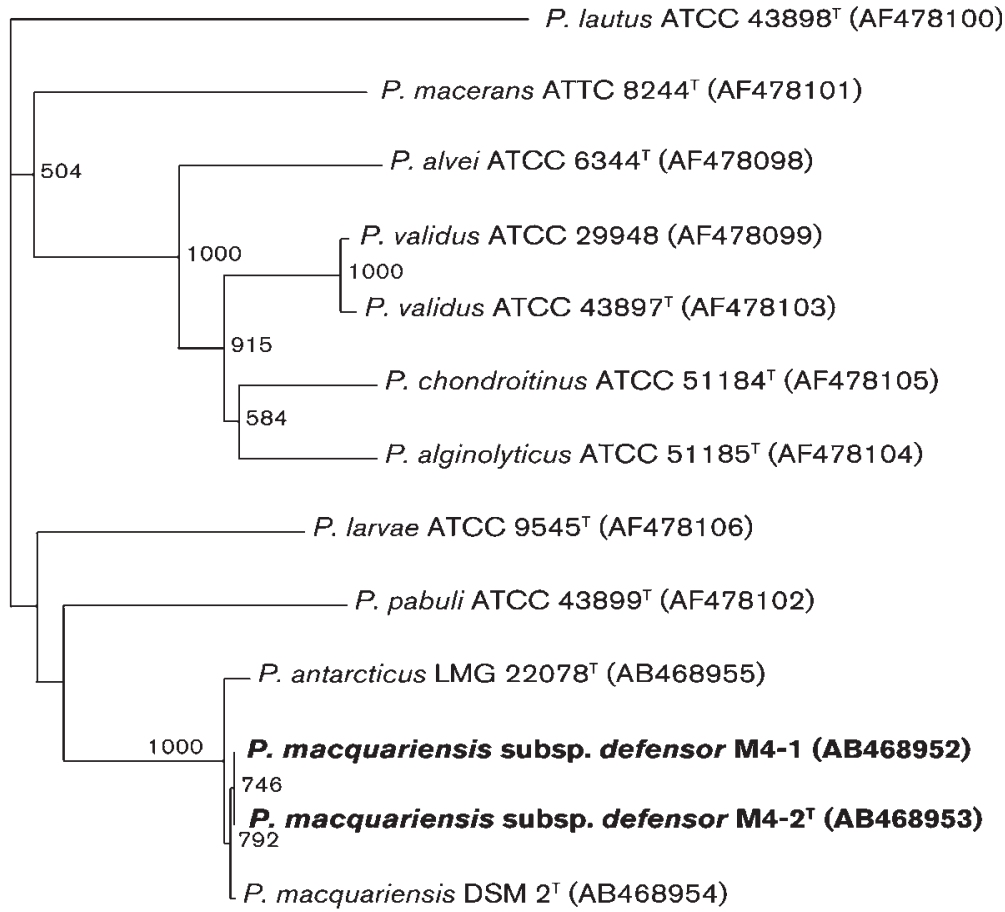

Fig. 2. Phylogenetic trees based on sequences of $r p o B(a), 16 S$ rRNA gene and 16S-23S ITS (b) and gyrB (c) from strains M4-2 ${ }^{\top}$ and M4-1 and phylogenetically related species of the genus Paenibacillus, constructed with the neighbour-joining method. Bootstrap values $(>50 \%)$ based on 1000 resamplings are shown at branch nodes. Bars, 0.1 substitutions per nucleotide position. 
Table 1. Phenotypic characteristics that differentiate strains M4-2 ${ }^{\top}$ and M4-1 from type strains of phylogenetically related Paenibacillus species

Strains: 1, M4-2 $2^{\mathrm{T}} ; 2$, M4-1; 3, P. macquariensis DSM $2^{\mathrm{T}} ; 4$, P. antarcticus LMG $22078^{\mathrm{T}}$. All data are from this study. All strains were negative for casein hydrolysis, gelatin liquefaction, nitrate reduction and VogesProskauer test. All strains produced acid from $N$-acetylglucosamine, amygdalin, L-arabinose, cellobiose, $\mathrm{D}$-fructose, galactose, $\beta$-gentiobiose, $\mathrm{D}$-glucose, methyl $\alpha$-D-xyloside, lactose, maltose, D-mannose, melibiose, methyl $\alpha$-D-glucoside, raffinose, ribose, salicin, starch, sucrose, trehalose, turanose and D-xylose, and none of the strains produced acid from adonitol, D-arabinose, D-arabitol, L-arabitol, dulcitol, erythritol, D-fucose, glycerol, inositol, inulin, 2-ketogluconate, 5-ketogluconate, rhamnose, sorbitol, L-sorbose, tagatose, xylitol and L-xylose. All strains hydrolysed starch and DNA and were able to grow at $4-5{ }^{\circ} \mathrm{C}$ and at $10{ }^{\circ} \mathrm{C}$. None of the strains grew in medium containing $5 \% \mathrm{NaCl}$ or at $32{ }^{\circ} \mathrm{C}$. + , Positive; - , negative.

\begin{tabular}{|lcccc|}
\hline Characteristic & $\mathbf{1}$ & $\mathbf{2}$ & $\mathbf{3}$ & $\mathbf{4}$ \\
\hline Growth at $\left({ }^{\circ} \mathrm{C}\right)$ : & & & & \\
$0-1$ & - & - & + & - \\
31 & + & + & - & + \\
Growth with 0.001 \% lysozyme & + & + & - & + \\
Oxidase & + & + & - & + \\
Acid production from: & & & & \\
Arbutin & + & + & + & - \\
L-Fucose & - & - & + & - \\
Gluconate & + & + & + & - \\
Glycogen & + & + & + & - \\
$\quad$ Mannitol & + & + & + & - \\
Methyl $\alpha$-D-mannoside & + & + & + & - \\
Melezitose & + & + & + & - \\
DNA G+C content $($ mol\%) & 42.8 & 41.7 & 39.0 & 40.7 \\
& & & & \\
\hline
\end{tabular}

Table 2. Cellular fatty acid compositions (\%) of strains $M 4-2^{\top}$ and M4-1 and type strains of phylogenetically related Paenibacillus species

Strains: 1, M4-2 $2^{\mathrm{T}} ; 2, \mathrm{M} 4-1 ; 3$, P. macquariensis DSM $2^{\mathrm{T}} ; 4, P$. antarcticus $\mathrm{LMG} 22078^{\mathrm{T}}$. All data are from this study.

\begin{tabular}{|c|c|c|c|c|}
\hline Fatty acid & 1 & 2 & 3 & 4 \\
\hline iso- $\mathrm{C}_{13: 0}$ & $<0.2$ & $<0.2$ & 0.7 & 0.6 \\
\hline anteiso- $\mathrm{C}_{13: 0}$ & $<0.2$ & $<0.2$ & 2.1 & 0.8 \\
\hline iso- $\mathrm{C}_{14: 0}$ & 2.7 & 3.1 & 3.3 & 5.0 \\
\hline $\mathrm{C}_{14: 0}$ & 1.4 & 1.3 & 1.7 & 3.0 \\
\hline iso- $\mathrm{C}_{15: 0}$ & 15.6 & 14.9 & 12.3 & 12.3 \\
\hline anteiso- $\mathrm{C}_{15: 0}$ & 63.0 & 64.7 & 61.3 & 54.5 \\
\hline $\mathrm{C}_{15: 0}$ & 2.5 & 1.4 & 3.8 & 1.5 \\
\hline iso- $\mathrm{C}_{16: 0}$ & 5.4 & 6.1 & 4.8 & 4.5 \\
\hline iso- $\mathrm{C}_{16: 1}$ & 0.6 & 0.5 & 0.5 & 0.9 \\
\hline $\mathrm{C}_{16: 0}$ & 3.9 & 3.7 & 5.1 & 8.8 \\
\hline$C_{16: 1}$ & 1.3 & 0.9 & 1.6 & 5.5 \\
\hline iso- $\mathrm{C}_{17: 0}$ & 1.4 & 1.3 & 1.2 & 1.0 \\
\hline anteiso- $\mathrm{C}_{17: 0}$ & 1.9 & 1.9 & 1.9 & 1.6 \\
\hline
\end{tabular}

$\alpha$-D-mannoside, trehalose, raffinose, turanose, $\beta$-gentiobiose, starch and glycogen. Acids are not produced from erythritol, L-xylose, xylitol, adonitol, D-arabinose, Darabitol, L-arabitol, dulcitol, D-fucose, glycerol, inositol, inulin, 2-ketogluconate, 5-ketogluconate, rhamnose, sorbitol, L-sorbose or tagatose. The cell wall contains meso-DAP. The major isoprenoid quinone is MK-7. The major fatty acids are anteiso- $\mathrm{C}_{15: 0}$ and iso- $\mathrm{C}_{15: 0}$.

The type strain, M4- $2^{\mathrm{T}}\left(=\mathrm{JCM} 14954^{\mathrm{T}}=\mathrm{NCIMB} 14397^{\mathrm{T}}\right.$ ), was isolated from boreal soil collected from the Koni Peninsula, Magadan Nature Reserve, Oblast Magadan, Russian Far East, Russia. The $\mathrm{G}+\mathrm{C}$ content of the genomic DNA of the type strain is $42.8 \mathrm{~mol} \%$.

\section{Description of Paenibacillus macquariensis subsp. macquariensis subsp. nov.}

The creation of Paenibacillus macquariensis subsp. defensor automatically creates the subspecies Paenibacillus macquariensis subsp. macquariensis subsp. nov. The description is the same as that given for Paenibacillus macquariensis by Marshall and Ohye (1966). The type strain is ATCC $23464^{\mathrm{T}}$ $\left(=\mathrm{DSM} 2^{\mathrm{T}}=\mathrm{LMG} 6935^{\mathrm{T}}=\right.$ NTCT $\left.10419^{\mathrm{T}}\right)$.

\section{Acknowledgements}

We are very grateful to Dr Aleksandra Berkutenko and Mr Anatoliy N. Michailov of the Institute of Biological Problems of the North, Far East Branch of the Russian Academy of Sciences, for the logistic support during the collection of soil samples from Magadan, Russia. We also thank the New Energy and Industrial Technology Development Organization (NEDO) of Japan for the financial support of our research project.

\section{References}

Ash, C., Priest, F. G. \& Collins, M. D. (1993). Molecular identification of rRNA group 3 bacilli (Ash, Farrow, Wallbanks and Collins) using a PCR probe test. Proposal for the creation of a new genus Paenibacillus. Antonie van Leeuwenhoek 64, 253-260.

Barrow, G. I. \& Feltham, R. K. A. (1993). Cowan and Steel's Manual for the Identification of Medical Bacteria, 3rd edn. Cambridge: Cambridge University Press.

Christner, B. C., Monsley-Thompson, E., Thompson, L. G. \& Reeve, J. N. (2001). Isolation of bacteria and $16 \mathrm{~S}$ rDNAs from Lake Vostok accretion ice. Environ Microbiol 3, 570-577.

Dahllöf, I., Baillie, H. \& Kjelleberg, S. (2000). rpoB-based microbial community analysis avoid limitations inherent in 16S rDNA gene intraspecies heterogeneity. Appl Environ Microbiol 66, 3376-3380.

Elo, S., Suominen, I., Kämpfer, P., Juhanoja, J., Salkinoja-Salonen, M. \& Haahtela, K. (2001). Paenibacillus borealis sp. nov., a nitrogen-fixing species isolated from spruce forest humus in Finland. Int J Syst Evol Microbiol 51, 535-545.

Ezaki, T., Hashimono, Y. \& Yabuuchi, E. (1989). Fluorometric deoxyribonucleic acid-deoxyribonucleic acid hybridization in microdilution wells as an alternative to membrane filter hybridization in which radioisotopes are used to determine genetic relatedness among bacterial strains. Int J Syst Bacteriol 39, 224-229. 
Hoshino, T. (2006). Ecophysiology of snow mold fungi. Curr Topic Plant Biol 6, 27-35.

Hsiang, T., Wu, C. \& Cook, S. (1999). Residual efficacy of Typhula phacorrhiza as a biocontrol agent of grey snow mold on creeping bentgrass. Can J Plant Pathol 21, 382-387.

Jordan, D. C., McNicol, P. J. \& Marshall, M. R. (1978). Biological nitrogen fixation in the terrestrial environment of a high arctic ecosystem (Truelove Lowland, Devon Island, N.W.T.). Can J Microbiol 24, 643-649.

Katsura, E., Ogawa, H., Kojima, H., Yano, S. \& Kaneshima, H. (1994). Runoff of fungicides used for prevention of snow molds in golf course. J Environ Chem 4, 831-840.

Kim, D. S., Cook, R. J. \& Weller, D. M. (1997). Bacillus sp. L324-94 for biological control of three diseases of wheat growth with reduced tillage. Phytopathology 87, 551-558.

Kimura, M. (1983). The Neutral Theory of Molecular Evolution. Cambridge: Cambridge University Press.

Logan, N. A., De Clerck, E., Lebbe, L., Verhelst, A., Goris, J., Forsyth, G., Rodríguez-Díaz, M., Heyndrickx, M. \& De Vos, P. (2004). Paenibacillus cineris sp. nov. and Paenibacillus cookii sp. nov., from Antarctic volcanic soils and a gelatin-processing plant. Int J Syst Evol Microbiol 54, 10711076.

Marshall, B. J. \& Ohye, D. F. (1966). Bacillus macquariensis n. sp., a psychrophilic bacterium from Antarctic soil. J Gen Microbiol 44, $41-46$.

Matsuyama, H., Hirabayashi, T., Kawahara, H., Minami, H., Hoshino, T. \& Yumoto, I. (2006). Glaciecola chathamensis sp. nov., a novel marine polysaccharide-producing bacterium. Int J Syst Evol Microbiol 56, 2883-2886.

Montes, M. J., Mercadé, E., Bozal, N. \& Guinea, J. (2004). Paenibacillus antarcticus sp. nov., a novel psychrotolerant organism from the Antarctic environment. Int J Syst Evol Microbiol 54, 15211526.

Oshiman, K. (2000). Sodium alginate as an adjuvant of an antagonistic bacterium, Pseudomonas fluorescens strain A11RN, to enhance biocontrol of turfgrass snow mold caused by Typhula ishikariensis. J Gen Plant Pathol 66, 258-263.

Pepi, M., Agnorelli, C. \& Bargagli, R. (2005). Iron demand by thermophilic and mesophilic bacteria isolated from antarctic geothermal soil. Biometals 18, 529-536.

Rodríguez-Díaz, M., Lebbe, L., Rodelas, B., Heyman, J., De Vos, P. \& Logan, N. A. (2005). Paenibacillus wynnii sp. nov., a novel species harbouring the nifH gene, isolated from Alexander Island, Antarctica. Int J Syst Evol Microbiol 55, 2093-2099.
Rosselló-Mora, R. \& Amman, R. (2001). The species concept for prokaryotes. FEMS Microbiol Rev 25, 39-67.

Saitou, N. \& Nei, M. (1987). The neighbor-joining method: a new method for reconstructing phylogenetic trees. Mol Biol Evol 4, 406425.

Shida, O., Takagi, H., Kadowaki, K., Nakamura, L. K. \& Komagata, K. (1997). Transfer of Bacillus aiginolyticus, Bacillus chondroitinus, Bacillus curdlanolyticus, Bacillus glucanolyticus, Bacillus kobensis, and Bacillus thiaminolyticus to the genus Paenibacillus and emended description of the genus Paenibacillus. Int J Syst Bacteriol 47, 289-298.

Stackebrandt, E. \& Goebel, B. M. (1994). Taxonomic note: a place for DNA-DNA reassociation and $16 \mathrm{~S}$ rRNA sequence analysis in the present species definition in bacteriology. Int J Syst Bacteriol 44, 846-849.

Stackebrandt, E., Frederiksen, W., Garrity, G. M., Grimont, P. A., Kämpfer, P., Maiden, M. C., Nesme, X., Rosselló-Mora, R., Swings, J. $\&$ other authors (2002). Report of the ad hoc committee for the reevaluation of the species definition in bacteriology. Int J Syst Evol Microbiol 52, 1043-1047.

Staneck, J. L. \& Roberts, G. D. (1974). Simplified approach to identification of aerobic actinomycetes by thin-layer chromatography. Appl Microbiol 28, 226-231.

Tamaoka, J. \& Komagata, K. (1984). Determination of DNA base composition by reversed-phase high-performance liquid chromatography. FEMS Microbiol Lett 25, 125-128.

Thompson, J. D., Higgins, D. G. \& Gibson, T. J. (1994). CLUSTAL W: improving the sensitivity of progressive multiple sequence alignment through sequence weighting, position-specific gap penalties and weight matrix choice. Nucleic Acids Res 22, 4673-4680.

Xu, D. \& Côté, J.-C. (2003). Phylogenetic relationship between Bacillus species and related genera inferred from comparison of $3^{\prime}$ end $16 \mathrm{~S}$ rDNA and 5' end 16S-23S ITS nucleotide sequences. Int J Syst Evol Microbiol 53, 695-704.

Yamamoto, S. \& Harayama, S. (1995). PCR amplification and direct sequencing of $\operatorname{gyr} B$ with universal primers and their application to the detection and taxonomic analysis of Pseudomonas putida strains. Appl Environ Microbiol 61, 1104-1109.

Yumoto, I., Yamazaki, K., Sawabe, T., Nakano, K., Kawasaki, K., Ezura, Y. \& Shinano, H. (1998). Bacillus horti sp. nov., a new Gramnegative alkaliphilic bacillus. Int J Syst Bacteriol 48, 565-571.

Yumoto, I., Yamazaki, K., Hishinuma, M., Nodasaka, Y., Suemori, A., Nakajima, K., Inoue, N. \& Kawasaki, K. (2001). Pseudomonas alkaliphila sp. nov., a novel facultatively psychrophilic alkaliphile isolated from seawater. Int J Syst Evol Microbiol 51, 349-355. 